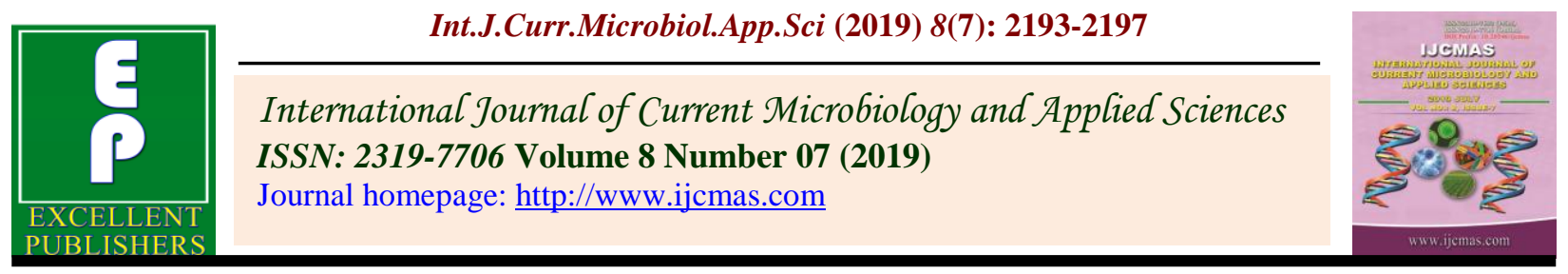

Original Research Article

https://doi.org/10.20546/ijcmas.2019.807.266

\title{
Isolation and Identification of Soil Fungi of Banana Fields form Baramati Area of Pune District of Maharashtra, India
}

\author{
Sandhya Shitole*, Vivek Kadam, Prasad Bankar, Anuradha Bhosale, \\ Sourabh Chandankar, Sujit Wagh and M.B. Kanade
}

P. G. Research Center, Department of Botany, Tuljaram Chaturchand College of Arts, Science and Commerce, Baramati, Dist. Pune - 413 102, Maharashtra, India

*Corresponding author

\begin{abstract}
A B S T R A C T
Present investigation emphasizes on isolation and identification of soil

Keywords

Banana (Musa paradisiaca $\mathrm{L}$.), Soil fungi

Article Info

Accepted:

17 June 2019 Available Online: 10 July 2019 fungi of banana (Musa paradisiaca L.) fields from Baramati area of Pune district of Maharashtra. The isolation of soil fungi was done by using serial dilution method and Potato Dextrose Agar (PDA) medium. Morphological characters of fungi were used for their identification. Total 22 fungal species were recorded throughout the study. The contribution of Deuteromycotina was $63.63 \%$ followed by Zygomycotina $18.18 \%$, Ascomycotina $13.63 \%$ and Mastigomycotina $4.54 \%$. During the study Aspergillus, Rhizopus, Trichoderma, Mucor, Alternaria, Curvularia, Fusarium, Penicillium and Rhizoctonia were noticed as predominant genera and Pythium, Chaetomium, Botrytis, Cladosporium, Drechslera, Helminthosporium and Nigrospora were found intermittently.
\end{abstract}

\section{Introduction}

Banana (Musa paradisiaca L.) is popular, important and commercial fruit crop of many tropical and sub-tropical regions of India. Banana fruits can play significant role in human nutrition by supplying the important growth factors such as vitamins and essential minerals (Muhammad et al., 2018). In India it is largely cultivated in Maharashtra, Tamil Nadu, Gujarat, Andhra Pradesh and Karnataka (Salve et al., 2019). It is cultivated in India an area of 830.5 thousand ha and total production is around 29,779.91 thousand tons (Gnanasekaran et al., 2015). Wide variety of bacteria, fungi, viruses and nematodes affected on banana crops and causes hazardous diseases. Among these the fungal diseases are most destructive once for example Fusarium wilt (Panama disease) is caused by the soil fungus Fusarium oxysporum (Tushemereirwe et al., 2004), Anthracnose is caused by Colletotrichum musae (Thangavelu et al., 2004), black sigatoka by 
Mycosphaerella fijiensis (Churchill, 2011), fruit rot by Botryosphaeria ribis, black root rot by Rosellinia bunodes and leaf spot caused by Curvularia eragrostidis (Jones, 1997). Fungal infection affected on yellowing, rusting and wilting of leaves, rotting of root, stem and fruits, decaying of fruits and ultimately affected on shelf life, nutritional profile and economy of fruits. In connection with this, the present study is designed to study the composition and concentration of soil fungi of banana fields from Baramati area of Pune district of Maharashtra.

\section{Materials and Methods}

The rhizosphere soil samples were collected from banana (Musa paradisiaca L.) fields of different localities of Baramati area during June, 2018 to April, 2019. The soil samples were collected in sterilized polythene bags and brought in laboratory for isolation of soil fungi. Serial dilution method was adopted for isolation of soil fungi (Aneja, 2003) using Potato Dextrose Agar (PDA) medium supplemented by Streptomycin antibiotic. Inoculated plates were kept for incubation at room temperature for 7 days. During the incubation period the fungal growth was observed regularly and observation were noted. After 7 days of incubation the photographs of plates were taken. Isolated fungal colonies were used for preparation of slides. Slides were prepared using cotton blue stain and lactophenol as mounting medium. Slides were observed under light microscope and micro-photography was also done. Fungi were identified on the basis of morphological characters of spores by using standard literature (Nagamani et al., 2006).

\section{Results and Discussion}

In the present study total 22 fungal species were noticed from rhizosphere soil samples of banana fields from Baramati area. Among these 04 species of Aspergillus, 03 species of Rhizopus and 02 species of Trichoderma and 01 species of Pythium, Mucor, Chaetomium, Alternaria, Botrytis, Cladosporium, Drechslera, Curvularia, Fusarium, Helminthosporium, Nigrospora, Penicillium and Rhizoctonia was noticed.

The percentage contribution of Deuteromycotina was maximum i.e. $63.63 \%$ followed by Zygomycotina $18.18 \%$, Ascomycotina $13.63 \%$ and Mastigomycotina 4.54\%. Aspergillus, Rhizopus, Trichoderma, Mucor, Alternaria, Curvularia, Fusarium, Penicillium and Rhizoctonia were found frequently during the study on the other hand Pythium, Chaetomium, Botrytis, Cladosporium, Drechslera, Helminthosporium and Nigrospora were found occasionally (Table 1).

Soils are extremely complex systems, with many components playing varied functions mainly due to the activity of soil organisms (Chiang and Soudi, 1994). Fungi are vital component of soils present very rich in amount compared to bacteria and other microorganisms (Gnanasekaran et al., 2015).

Fungal flora of agricultural soils is affected by various physico-chemical properties of soil. Organic content, moisture and $\mathrm{pH}$ of soil have great impact on fungal diversity of any soil (Gaddeyya et al., 2012). The fungal diversity of soils affected positively as well as negatively on growth of crop plants (Ratna Kumar et al., 2015).

Gnanasekaran et al., (2015) studied the soil mycoflora of banana field at Manachanallur, Tiruchirappalli, Tamil Nadu and recorded 65 fungal species belonging to 26 genera. Furthermore they reported that Aspergillus, Penicillium and Trichoderma were dominant genera. Fungal diversity from rhizosphere soil of banana fields at Jalgaon district of 
Maharashtra was studied by Salve et al., (2019). They analyzed eighteen banana field's rhizosphere soils and reported total 1354 fungal colonies belonging to 35 fungal species and 21 genera. They found Cladosporium, Fusarium and Aspergillus as dominant species. Kumar and Saxena (2015) isolated the fungi from infected banana stem and banana field soils and reported 19 fungal species belonging to 13 genera.

Furthermore they reported that, the Fusarium showed maximum percentage contribution in rhizosphere soil i.e. $83.4 \%$. Same results were also found in our investigation.

Fungal diversity of rhizosphere soils from paddy, pulses, ragi, sugarcane, vegetables and banana fields of Nanjangud taluk of Mysore district, Karnataka were studied by Chandrashekar et al., (2014). They described total of 10 fungal species belonging to 7 genera from studied agricultural fields and found that Aspergillus, Penicillium and Mucor species were dominant throughout the investigation.

Table.1 Soil mycoflora of banana fields form Baramati Area of Pune District

\begin{tabular}{|c|c|c|}
\hline Sr. No & Fungi & Division \\
\hline 1. & Pythium debaryanum & Mastigomycotina \\
\hline 2. & Rhizopus oryzae & Zygomycotina \\
\hline 3. & Rhizopus stolonifer & Zygomycotina \\
\hline 4. & Rhizopus sp. & Zygomycotina \\
\hline 5. & Muсог тисеdo & Zygomycotina \\
\hline 6. & Chaetomium globosum & Ascomycotina \\
\hline 7. & Trichoderma viride & Ascomycotina \\
\hline 8. & Trichoderma harzianum & Ascomycotina \\
\hline 9. & Alternaria alternata & Deuteromycotina \\
\hline 10. & Aspergillus sp. & Deuteromycotina \\
\hline 11. & Aspergillus brunneo-uniseriatus & Deuteromycotina \\
\hline 12. & Aspergillus kanagawaensis & Deuteromycotina \\
\hline 13. & Aspergillus niger & Deuteromycotina \\
\hline 14. & Botrytis sp. & Deuteromycotina \\
\hline 15. & Cladosporium sp. & Deuteromycotina \\
\hline 16. & Drechslera sp. & Deuteromycotina \\
\hline 17. & Curvularia lunata & Deuteromycotina \\
\hline 18. & Fusarium oxysporum & Deuteromycotina \\
\hline 19. & Helminthosporium sp. & Deuteromycotina \\
\hline 20. & Nigrospora sp. & Deuteromycotina \\
\hline 21. & Penicillium aurantiogriseum & Deuteromycotina \\
\hline 22. & Rhizoctonia sp. & Deuteromycotina \\
\hline
\end{tabular}

Muhammad et al., (2018) studied the fungi associated with spoilage of sweet orange (Citrus sinensis) and banana (Musa sapientum) from Sokoto, Metropolis. During the investigation they found most predominant fungi isolated from sweet orange were Cladosporium sp. (40\%), Fusarium sp. (30\%), Alternaria sp. (20\%) and Chrysonilia sp. (10\%) while from banana were Fusarium sp. (50\%), Mucor sp. (30\%) and Rhizopus sp. 
(20\%). Ratna Kumar et al., (2015) analyzed the soil samples of paddy fields from 05 different localities of Tekkali Mandal, Srikakulam, AP to study fungal diversity and reported 18 species belonging to 6 genera of fungi. Among these Aspergillus flavus, A. fumigatus, A. nidulans, A. niger, A. terreus, Penicillium chrysogenum, $P$. frequentens were predominant. Isolation and identification of soil mycoflora from paddy, corn, ragi, red gram, cotton and sugarcane crop fields at Salur Mandal were investigated by Gaddeyya et al., (2012). They noticed total of 15 fungal species belonging to 6 genera and found Aspergillus flavus, A. fumigatus, A. niger, A. nidulans, $A$. terreus, $P$. chrysogenum, $P$. frequentans, $P$. funiculosum, Trichoderma viride, T. harzianum, Fusarium oxysporum, $F$. solani, Curvularia clavata, C. lunata and Rhizopus stolonifer as most dominant genera during the study.

Taking into consideration of our results and literature survey it may be concluded that, the Deuteromycotina fungi frequently found in soil because of their faster rate of asexual reproduction, as they causes diverse diseases to crop plants and their abundant flora in air and soil.

\section{Acknowledgements}

Authors are sincerely thankful to Dr. Chandrashekhar Murumkar, Principal and Head, P. G. Research Center, Department of Botany, Tuljaram Chaturchand College of Arts, Science and Commerce, Baramati, Dist. Pune, MS, India for his constant guidance and encouragement.

\section{References}

Aneja K. R. (2003). Experiments in Microbiology. Plant Pathology and Biotechnology New age International Publication.
Chandrashekar, M.A., Soumya Pai K. and Raju, N. S. (2014). Fungal diversity of rhizosphere soils in different agricultural fields of Nanjangud Taluk of Mysore District, Karnataka, India. International Journal Current Microbiology and Applied Sciences, 3(5): 559-566.

Chiang, C.N., Soudi, B. (1994). Biologie du sol et cycles biogeochimiques In: EI Hassani TA. and person E (Eds). Agronomie Moderne, Bases physiologiques et agronomiques de la production vegetale, 85-118.

Churchill, A. C. (2011). Mycosphaerella fijiensis, the black leaf streak pathogen of banana: progress towards understanding pathogen biology and detection, disease development, and the challenges of control. Molecular Plant Pathology, 12(4): 307-28.

Gaddeyya, G., Shiny Niharika, P., Bharathi, P. and Ratna Kumar P. K. (2012). Isolation and identification of soil mycoflora in different crop fields at Salur Mandal. Advances in Applied Science Research, 3(4): 2020-2026.

Gnanasekaran. P, Mohamed Salique. S. and Panneerselvam, A. (2015). Isolation and identification of soil mycoflora in Banana field at Manachanallur, Tiruchirappalli Dt., Tamilnadu, India. International Journal of Current Microbiology and Applied Sciences, 4(7): 729-740.

Jones David R. (1997). Common Names of Diseases, Diseases of Banana and Plantain (Musa sp.). The American Phytopathological Society.

Kumar, N. and Saxena, N. (2015). Fusarium Wilt of Banana at Panchgaon. International Journal of Current Microbiology and Applied Sciences, 4(11): 724-730.

Muhammad, AS., Mohammed. IU, Ameh, M., Bell I., Haliru BS, Bagudo HA, Sanda, 
A. (2018). Isolation and identification of fungi associated with the spoilage of sweet orange (Citrus sinensis L) and banana (Musa sapientum L) in Sokoto Metropolis. Journal of Applied Biotechnology \& Bioengineering, 5(3): 172-182.

Nagamani, A, Kunwar, I. K, Manoharachary. C. (2006). Handbook of soil fungi. I. K. International pvt. Ltd., New Delhi.

Ratna Kumar. P.K, Hemanth. G, P. Shiny Niharika and Samuel, K. Kolli (2015). Isolation and identification of mycoflora in agricultural fields at Tekkali Mandal in Srikakulam District. International Journal of Advances in pharmacy, Biology and Chemistry, 4 (2): 484-490.
Salve Sadhana, Rajurkar Suchita, Gaikwad Swati (2019). Fungal diversity in rhizosphere soil of banana fields at Jalgaon district, (MS). International Journal of Sciences and Research, 8(3): 110-113.

Thangavelu, R., Sundararaju, P. and Sathiamoorthy, S. (2004). Management of anthracnose disease of banana caused by Colletotrichum musae using plant extracts, The Journal of Horticultural Science and Biotechnology, 79(4): 664668.

Tushemereirwe, W.K., Kangire, A., Kubiriba, J., Nakyanzi, M. and Gold, C.S. (2004). Diseases threatening banana biodiversity in Uganda. African Crop Science Journal, 12(1): 19-26.

\section{How to cite this article:}

Sandhya Shitole, Vivek Kadam, Prasad Bankar, Anuradha Bhosale, Sourabh Chandankar, Sujit Wagh and Kanade, M.B. 2019. Isolation and Identification of Soil Fungi of Banana Fields form Baramati Area of Pune District of Maharashtra, India. Int.J.Curr.Microbiol.App.Sci. 8(07): 2193-2197. doi: https://doi.org/10.20546/ijcmas.2019.807.266 